\title{
Türkiye Enflasyon Görünümüne İlişkin Bir Değerlendirme; Reel Efektif Döviz Kuru İle Tüketici Fiyat Endeksi Arasındaki İlişkinin Analizi *
}

\section{A Review of Inflation Outlook in Turkey; Analysis of the Relationship between Real Effective Exchange Rate and Consumer Price Index}

Esra N. K1lc1 ${ }^{\mathrm{a}, * *}$

a Dr. Öğr. Üyesi, İstanbul Arel Üniversitesi, İktisadi İdari Bilimler Fakültesi, Uluslararası Ticaret ve Finans Bölümü, İstanbul/Türkiye. ORCID: 0000-0002-2239-4560.

\section{MAKALE BILGİSİ}

Makale Geçmişi:

Başvuru tarihi: 05 Şubat 2019

Düzeltme tarihi: 11 Temmuz 2019

Kabul tarihi: 17 Temmuz 2019

Anahtar Kelimeler:

Tüketici Fiyat Endeksi,

Reel Efektif Döviz Kuru,

TCMB
ÖZ

Türkiye'de, 2006 y1lından itibaren uygulanan "Enflasyon Hedeflemesi” rejimi ile enflasyonda belirgin bir iyileşme sağlanmıştır. Ancak, 2016 yılı ikinci yarısından itibaren ve özellikle 2018 yılında döviz kurunda Türk Lirası aleyhine yaşanan aşırı değerlenme, enflasyonda yukarı yönlü trendi desteklemiş, 2018 y1lsonu enflasyon oranı \%20,30 seviyesinde gerçekleşmiştir. Türkiye Cumhuriyeti Merkez Bankası (TCMB) tarafindan, para politikası faiz oranlarında belirgin bir faiz artırımı yapılmıș; Rezerv Opsiyon Mekanizması (ROM) kapsamında dövize ilișkin üst sınırın indirilmesi ve yabancı para zorunluk karşılık oranlarının arttırılması gibi adımlar atılarak, kurdaki yukarı hareketler sınırlandırılmaya çalışılmıştır. Bu çalışmanın amacı, reel efektif döviz kuru ile tüketici fiyat endeksi arasındaki ilişkinin, 2003:01-2018:12 dönemi aylık verileri esas alınarak ve Fourier ADF birim kök, Fourier SHIN kointegrasyon ve Fourier Granger nedensellik testlerinin kullanılarak analiz edilmesidir. Çalışma sonuçları, reel efektif kur ve tüketici fiyat endeksi arasında kısa ve uzun dönemli ilişki olduğunu göstermektedir.

\section{ARTICLE INFO}

\section{Article history:}

Received 05 February 2019

Received in revised form 11 July 2019

Accepted 17 July 2019

\section{Keywords:}

Consumer Price Index,

Real Effective Exchange Rate,

CBRT

\begin{abstract}
A B S T R AC T
Turkey experienced a significant improvement in the inflation thanks to the "Inflation Targetting" regime which has been implemented since 2006. However, the appreciation in the foreign exchange rates against Turkish Lira in the period from 2016 to 2018, supported the upward trend in inflation and led to a \%20,30 year-end inflation rate in 2018. In response to the developments, the Central Bank of the Republic of Turkey (CBRT) made significant interest rate increase. At the same time, steps have been taken to reduce the upper limit for foreign exchange rates within the scope of the ROM and to increase the foreign exchange reserve requirements. The objective of this study is to investigate the relationship between real effective exchange rate and consumer price index in the period of 2003:01-2008:12 by using monthly data and by employing Fourier ADF unit root, Fourier SHIN cointegrasyon and Fourier Granger causality tests. The findings indicate that real effective exchange rate does have impact on consumer price index in both short and long-run.
\end{abstract}

\section{Giriş}

Türkiye'de 2016 yılı ikinci yarısından itibaren ve özellikle 2018 yılında döviz kurunda Türk Lirası aleyhine yaşanan aşırı değerlenme, enflasyon başta olmak üzere birçok makroekonomik göstergeyi olumsuz yönde etkilemiştir.
Toplam talepteki azalmanın yarattığı dezenflasyonist etkiye rağmen, döviz kurundaki aşırı değerlenme ve ithal mal fiyatlarındaki belirgin yükselişlerin yanı sıra, beklentiler ve buna paralel olarak ekonomik birimlerin fiyatlama davranışındaki bozulmanın tetiklediği fiyat artışları enflasyonun yukarı yöndeki hareketini desteklemiş; 2018

* Bu çalışma, 4-5 Mayıs 2018 tarihleri arasında Adana'da düzenlenen II. Uluslararası Multidisipliner Çalışmaları Kongresi’nde sunulan “Türkiye Enflasyon Görünümüne İlişkin Bir Değerlendirme” isimli sözlü bildirinin genişletilmiş ve revize edilmiş halidir.

** Sorumlu yazar/Corresponding author 
y1lında \%20,30 seviyesinde (TÜIK, 2019) bir yılsonu enflasyon oranını beraberinde getirmiştir. Bilindiği üzere, Türkiye'de 2006 y1lından itibaren enflasyon hedeflemesi rejimi uygulanmakta olup, söz konusu programla birlikte, uygulanan mali disiplin ve TCMB'nin etkin para politikası sonucunda, enflasyon oranı tek hanelere düşürülmüş; 2002 öncesi dönemde aşırı yüksek seviyelerde seyreden enflasyon oranlarında belirgin bir iyileşme görülmüştür.

Özellikle enflasyon hedeflemesi rejimi uygulayan ülkeler için, enflasyona yol açan faktörlerin tespit edilmesi ve bu faktörlerin iyileştirilmesi büyük önem arz etmektedir. Gelişmekte olan ülkelerde, döviz kuru ve buna bağlı olarak ithal ürünlerin fiyatları, özellikle kısa dönemde, enflasyona yol açan temel dinamiklerdendir ve söz konusu faktörlerde hızlı ve büyük değişimler yaşandığı dönemlerde, mali otoriteler ve para otoriteleri açısından bu faktörlerin önemi artmaktadır (Özmen ve Topaloğlu, 2017: 1). Aynı zamanda, uluslararası entegrasyonun artması, gelişmekte olan ülke finansal piyasaları arasındaki bağlantıların artmasına büyük ölçüde katkıda bulunmuştur. Döviz kuru hareketlerinden ülke içi fiyatlara olan aktarım, enflasyonun ve ekonomik döngülerin uluslararası aktarımında yer alan önemli bir kanaldır ve döviz kuru aktarım kanalı olarak adlandırılmaktadır (Aron vd., 2014: 1). Döviz kurlarındaki değişim ve enflasyon arasındaki bağlantıyı güçlendiren faktörler; ithal ürünlerin ülke ekonomisi içerisindeki ağırlığının yüksek olması, söz konusu ürünlerin ülke içinde üretilebilirliğinin zor olması ve aynı zamanda, küresel emtiaenerji fiyatlarındaki artışlardır.

Döviz kurundaki değişimler, direkt olarak ve hızlı bir şekilde, ülke içerisindeki malların fiyatlarına yansımaktadır. Aynı zamanda, döviz kurlarında ülke parası aleyhine yaşanan değişimler, ithal malların ülke parası cinsinden değerini arttırmakta ve bu yolla tüketici fiyat endeksinin yükselmesine yol açmaktadır. TÜFE sepeti içerisinde ticarete konu olan malların payı arttıkça, bu etki güçlenmektedir. Döviz kurları, domestik (yurt içi) fiyatları "endeksleme" kanalı aracılığıyla da etkilemektedir. Enflasyonun süreklilik arz ettiği bir ekonomik ortamda, yani domestik fiyatların ölçü birimi ve değer birikim aracı işlevlerini kaybettiği bir atmosferde, yüksek oranlı bir endeksleme dikkati çekmektedir. Ayrıca, sabit ve sabit benzeri kur sistemlerinde, fiyat alıcılar, döviz kurlarını nominal bir çapa olarak görmektedir. Bu etki, dalgalı kur sistemlerinde, özellikle döviz kurlarında dalgalanmalar yaşandığı dönemlerde, ekonomik birimlerin döviz kurundaki değişimleri esas alarak hareket etmeleri ve dolarizasyon eğiliminin artması şeklinde gerçekleşmektedir. Hızlı ve büyük ölçekli devalüasyonların veya değer kayıplarının yaşandığ1 ve yüksek enflasyonun var olduğu dönemler, döviz kurunun işlemlerde ve finansal sözleşmelerde yaygın şekilde kullanımına yol açarak, maliyet kanalının ötesinde, döviz kuru aktarım mekanizmasının derecesini arttırmaktadır. Dolayısıyla, ithal edilen ara malı ve nihai mallar aracılığıyla çalışan maliyet kanalına ek olarak, "beklentiler" yoluyla, döviz kurlarından domestik fiyatlara doğru başka bir aktarım kanalı daha ortaya çıkmaktadır (Kara vd., 2007: 207).
Türkiye gibi ülkelerde, yurtdışından büyük ölçekte hammadde ve ara malı ithalatı yapıldığı için, üretim maliyetlerinin içerisinde büyük oranda yabancı girdi unsuru bulunmaktadır. İthal edilen hammadde ve ekipman maliyeti firmaların üretim maliyetleri içerisinde büyük bir ağırlığa sahiptir. Enerji unsuru dikkate alındığında, ortalama maliyetler daha da artmaktadır. İthal ürün fiyatları ve döviz kurlarının tüketici fiyat endeksini önemli ölçüde tetiklediğine işaret eden çalışmalar, enflasyon dinamiklerini incelerken, bu konu üzerinde dikkatle durmaktadır (Andıç vd., 2015: 4). Diğer yandan, enflasyon hedeflemesi rejimiyle birlikte dalgalı kur sistemine geçilmesinin, döviz kurları ile diğer nominal değişkenler arasındaki ilişkiyi dolayısıyla aktarım mekanizmasını zayıflatması beklenmektedir (Kara vd., 2007: 206). Bununla beraber, ithal mallara olan bağımlılık ve enerjinin üretim sürecinde ana girdilerden biri olması gibi faktörler, döviz kuru aktarım mekanizmasının etkisini arttırmaktadır.

Türkiye'de son iki yıllık dönemde döviz kurunda yaşanan aşırı değerlenme, enflasyonda yukarı yönde trendi desteklemiştir. 2001 yılında \%70'lerde seyreden enflasyon oran1, 2008 ve 2011 y1lları haricinde tek hanelerde kalmayı sürdürmüş, 2017 ve 2018 yılında ise tekrar çift haneli bir değer alarak enflasyon hedeflerinin ulaşılabilirliği ile ilgili soru işaretlerini beraberinde getirmiştir. $\mathrm{Bu}$ çalışmanın amacı, reel efektif döviz kuru ile tüketici fiyat endeksi arasındaki ilişkinin, 2003:01-2018:12 dönemi aylık verileri esas alınarak ve Fourier ADF birim kök, Fourier SHIN kointegrasyon ve Fourier Granger nedensellik testlerinin kullanılmasıyla çok sayıda yapısal kırılmanın etkisinin dikkate alınarak analiz edilmesidir. Enders ve Lee (2012) tarafından geliştirilen Fourier ADF birim kök testi, birden fazla yapısal değişimin düşük frekanslı Fourier fonksiyonlarıyla tahmin edilmesine olanak sağlamaktadır. Diğer birçok yöntemin aksine, yapısal değişimin sayı ve konumunu bilmek zorunluluğu ortadan kalkmaktadır. İzleyen aşamada kullanılan, Tsong vd. (2016) tarafindan geliştirilen Fourier SHIN eşbütünleşme testi ise, yapısal değişimlerin formuna ve sayısına karşın güçlü sonuçlar türetmektedir. Son olarak, üçüncü aşamada değişkenler arasındaki nedensellik ilişkisinin araştırılması amacıyla, Enders ve Jones (2016) tarafından geliştirilen Fourier Granger nedensellik testine başvurulmaktadır. $\mathrm{Bu}$ testte, esnek Fourier formu kullanılarak, VAR sistemi içerisinde var olan yumuşak kırılmalar yakalanmaya çalışılmaktadır. $\mathrm{Bu}$ testlerin kullanılmasıyla, analiz sonuçlarının güvenilirliği arttırılmaya çalışılmaktadır.

Çalışmanın izleyen bölümleri aşağıdaki şekildedir; 2 . ve 3 . Bölüm'de sırasıyla, dünya ekonomisindeki gelişmelere ve Türkiye enflasyon görünümüne değinilmiştir. 4. Bölümde, literatür araştırmasının sunulmasını takiben, 5. Bölüm'de, Fourier ADF birim kök testi, Fourier SHIN eşbütünleşme testi ve Fourier Granger nedensellik testi çerçevesinde analiz sonuçlarına yer verilmiş ve 6. Bölüm'de yer alan Sonuç kısmı ile konuya ilişkin genel bir değerlendirme yapılmıştır. 


\section{2018 Yılına İlişkin Dünya Ekonomik Görünümü ve Beklentiler}

2018 yılı, hem gelişmiş ülke hem gelişmekte olan ülke ekonomileri açısından zor bir yıl olmuştur. Küresel finansal koşullarda sıkılaşma devam etmiş; ABD Merkez Bankası (FED)'nın faiz artırım sürecine paralel olarak, uzun dönem faiz oranlarında yukarı yönlü bir trend hakim olmuştur. Gelişmekte olan ülkelerde risk priminin artması, sermaye çıkışlarının hızlanmasına ve ülke para birimlerinde değer kayıplarına yol açmıştır. Ortadoğu'da yaşanan sıkıntılı süreç, mülteci sorunu, Brexit referandumu gibi faktörler, özellikle 2016 y1lından itibaren artan jeopolitik risklerle birlikte, global kırılganlıkları ve ekonomik belirsizliği artıran gelişmeler olmuştur. Uluslararası Para Fonu (IMF) ve Dünya Bankası tarafından yayımlanan raporlara göre, ekonomik performans açısından olumsuz gelişmeleri teşvik edecek faktörlerin 2019 yılında da varlığını sürdüreceği tahmin edilmektedir. Geçtiğimiz yıllarda, gelişmiş ülkelerde, düşük enflasyon oranlarının varlığ programları gibi genişleyici para politikalarının sürdürülmesine ve büyümenin desteklenmesine yol açarken, son dönemde enflasyonist endişelerin ortaya çıkması, ki petrol fiyatlarındaki yukarı yönlü hareketler de gelişmiş ülkelerde enflasyonist eğilimleri destekleyen faktörlerdendir, FED'in 2018 y1lında gerçekleştirdiği ve 2019 yılında sürdüreceği faiz artırımları, özellikle gelişmekte olan ülkelerde, finans ve döviz piyasalarında volatilitenin artmasına ve sermaye akımlarında olumsuz hareketlere yol açmaktadır.

2018 yılında, global anlamda ekonomik aktivitede kısmi yavaşlama görülmüş, Euro-Bölgesi ve İngiltere'de ticaret hacmi ve sanayi üretimi gerilemiştir. Türkiye, Arjantin ve Brezilya'da yatırımcı algısındaki bozulma sermaye çıkışlarını hızlandırmış, döviz kurlarındaki aşırı oynaklık, döviz kuru aktarım mekanizması aracılığıyla, enflasyonun yükselmesine katkıda bulunmuştur. İzleyen dönemde, ABD tarafindan izlenen korumacı politikaların ihracata dayalı büyüme sergileyen Japonya ve Çin gibi ülkelere zarar vereceği ve ekonomik büyümeyi sekteye uğratacağı düşünülmektedir. Avrupa Birliği'nde ise işgücü piyasasını iyileştirici ve ihracatı arttırıcı önlemler alınmasına rağmen, Brexit referandumu sonucu artan politik belirsizliğin, genişleyici para ve maliye politikalarının yumuşatıcı etkisine rağmen, yatırımlara zarar vermesi ve ekonomik aktivitenin daralmasına yol açması beklenmektedir (Dünya Bankası Raporu; 2018, s. 17). IMF (2018) Ekim Ayı Raporu'na göre, küresel büyümeyi negatif yönde etkileyecek risklerde görülen artış nedeniyle, büyüme tahmini \%3,7 seviyesine aşağı yönlü revize edilmiştir. ABD tarafindan özellikle Çin'e yönelik tarifelerin arttırılmasını da içeren ticaret önlemlerinin olumsuz etkileriyle, Avrupa Birliği'nde olası sıkıntıların büyümeyi aşağı yönlü etkileyeceği öngörülmektedir. Arjantin, Brezilya, İran ve Türkiye'nin içinde bulunduğu gelişmekte olan ülkelerde, ülkeye özgü dinamiklerdeki bozulma, finansal koşullardaki sıkılaşma, jeopolitik gerilimdeki artış gibi faktörler nedeniyle, büyümeye ilişkin beklentiler aşağı yönlü revize edilmiştir. Gelişmiş ülkelerdeki finansal sıkılaştırma, finansal kırılganlığı artan bu ülkelere olan portföy yatırımlarında azalmaya, döviz kurlarında aşırı dalgalanmalara ve sermaye çıkışlarına yol açabilecektir.

\section{Türkiye'de 2018 Yılına İlişsin Enflasyon Görünümü ve Beklentiler}

Aslında, geçtiğimiz on yıllık dönemde dünya ekonomisinde $A B D$ ve $A B$ 'de ortaya çıkan finansal türbülanslar, ekonomik aktivitenin belirgin şekilde yavaşlamasına yol açmı̧̧; uluslararası entegrasyonun yüksek olması ve yayılma etkisiyle, Türkiye'nin de aralarında bulunduğu birçok ülke ekonomisini olumsuz yönde etkilemiştir. Bununla beraber, Türkiye ekonomik ve finansal görünümünde ciddi bir bozulma görülmemiştir. Ancak son dönemde, enflasyonun da içinde bulunduğu bazı makroekonomik değişkenlerde kısmen olumsuz bir görünüm ortaya çıkmıştır. 2001 y1lında \%70'lerde seyreden enflasyon oran1, 2008 ve 2011 y1lları haricinde tek hanelerde kalmayı sürdürmüş, 2017 ve 2018 yıllarında ise tekrar çift haneli bir değer alarak enflasyon hedeflerinin ulaşılabilirliği ile ilgili soru işaretlerini beraberinde getirmiştir. 2018 yılında, özellikle yılın ikinci yarısında enerji fiyatlarındaki artış, gelişmiş ve gelişmekte olan ülkelerdeki enflasyonun yükselmesinde belirleyici etkenlerden biri olmuştur.

TÜİK tarafından açıklanan verilere göre, yılsonu enflasyon oran1 2017'de \%11,92 ve 2018'de \%20,30 seviyesinde gerçekleşmiş olup; söz konusu oranın 2016 yılsonunda aldığı değer \%8,53 seviyesindedir. İthalatın ekonomi içerisindeki ağırlığı göz önüne alındığında, kur artışının ithal enflasyonunun artmasına önemli ölçüde katkıda bulunduğu ve petrol başta olmak üzere enerji fiyatlarında global anlamda yaşanan kısmi yükselişle beraber kurdaki artışın, Türkiye ciddi anlamda enerji ithal eden bir ülke olduğu için, enflasyona yukarı yönde etki yaptığı görülmektedir. Enflasyonun yukarı yönde hareketinde etkili olan bir diğer önemli faktör ise gıda fiyatlarındaki artıştır. Türkiye'de, genel anlamda tüm gelişmekte olan ülke ekonomilerinde yaşanan risk primi artışına ek olarak, politik belirsizlikte yaşanan belirgin artış, özellikle Ağustos ayında, döviz kurlarında şiddetli dalgalanmalara neden olmuş, Eylül ayında TCMB tarafından gerçekleştirilen 625 baz puanlık artırım vb. önlemler ile kurlardaki dalgalanmanın önüne geçilebilmiştir.

Döviz kurlarında Türk Lirası aleyhine yaşanan şiddetli dalgalanma ve enflasyonist beklentilerdeki artış, piyasa faiz oranlarında ve bunun sonucunda banka kredi oranlarında yukarı yönlü trendi desteklemiştir. Faiz artışlarının, izleyen dönemde firma finansman giderlerini arttırması ve arz kaynaklı enflasyon üzerinde yukarı yönlü trendi besleyeceği öngörülmektedir. TCMB, 4. Çeyrek Enflasyon Raporu (2018)'ndan alınan bilgilere göre, enflasyonda 2018 yılında görülen belirgin yukarı harekette ana sebep olarak, döviz kurlarında yaşanan aşırı yükseliş gösterilmesine rağmen, tüm alt kategorilerde yaşanan artış ve döviz kuru aktarım mekanizmasının göreceli olarak düşük çalıştığı bazı gruplarda gözlenen fiyat artışları, aslında ekonomik birimlerin fiyatlama davranışında bir bozulmaya işaret etmektedir. Talep yönlü koşullardaki kötüleşme 
dezenflasyonist etkiyi k1smi anlamda desteklerken, maliyetlerdeki artış nedeniyle arz yönlü baskıların artması, enflasyonun artış yönündeki hareketini desteklemiştir. Ayrıca, ekonomik aktivitede, döviz kurlarındaki yüksek dalgalanma ve finansal koşullardaki sıkılaştırma nedeniyle, önünüzdeki dönemde kısmi bir daralma yaşanması beklenmektedir.

Yine aynı raporda, işlenmemiş yiyecekler, alkol ve tütün ürünlerinin hariç tutulduğu tüketici fiyat endeksinde de artış gözlemlendiğine yer verilmiştir. Buna göre, özellikle yılın ikinci yarısında, yıllık enflasyonu tetikleyen ana faktör, döviz kurundaki gelişmelere oldukça duyarlı olan çekirdek mal grubu fiyatlarındaki artıştır. Yüksek oranda ithal girdi içeren dayanıklı mallar grubunda, özellikle beyaz eşya ve otomobil gibi mal gruplarında, yüksek fiyat artışları hissedilirken; hem işlenmiş hem de işlenmemiş yiyecek gruplarında, enflasyon görünümünde bozulma yaşanmıştır. Elektrik ve doğal gazdaki fiyat artışları, enerji grubundaki enflasyonu desteklerken; petrol fiyatlarındaki yukarı yöndeki trende rağmen, fiyat artışlarının vergiden feragat edilerek pompa fiyatlarına yansıtılmaması, enflasyondaki olası baskıları kısmen frenlemiştir. Hizmet enflasyonunda da, Türk Lirası'nda yaşanan değer kaybı, geriye doğru endeksleme, yiyecek ve enerji enflasyonundaki kötüleşme nedeniyle yukarı hareket yaşanmıştır.

\section{Literatür Araştırması}

Döviz kurlarındaki değişimlerin yurtiçi fiyatlardaki etkisinin ve yönünün tespit edilmesi, ülke para otoriteleri tarafindan büyük önem taşımaktadır ve bu konuda yapılan çalışmalar, akademik literatürde geniş yer kaplamaktadır. Diğer gelişmekte olan ülkelerde olduğu gibi, Türkiye'de de döviz kurlarından enflasyona aktarım mekanizması üzerine yapılan çalışmalar mevcuttur. Aşağıda, bu çalışmalara kısaca yer verilmiştir.

Gül ve Ekinci (2006), Türkiye'de nominal döviz kurları ile enflasyon arasındaki ilişkiyi, 1984:01-2003:12 dönemi aylık verilerini kullanarak araştırmışlar; döviz kurlarından enflasyona doğru bir nedensellik ilişkisi tespit etmişlerdir. Buna göre, söz konusu dönemde, döviz kurları, Türkiye'de enflasyonun temel determinantlarından birisidir.

Kara ve Öğünç (2008), vektör oto-regresyon modelini kullanarak, ithal enflasyondan enflasyon oranına aktarım mekanizmasını analiz etmişlerdir. Analiz sonuçları, Türkiye'de geçmişte döviz kuru aktarım mekanizmasının hızlı ve yüksek iken, enflasyon hedeflemesi rejimine geçilmesiyle aktarım mekanizmasının zayıfladığını göstermektedir. Buna göre, enflasyon hedeflemesi rejiminin başarılı bir şekilde yürütülmesinin büyük ölçüde beraberinde getirdiği, Merkez Bankası'nın kredibilitesindeki artış, döviz kurlarındaki olumlu trend ve beklenti oluşumundaki değişim gibi nedenler bu durumda etkili olan faktörler olmuştur. Kara ve Ögünç, enflasyon hedeflemesi rejiminin bizzat kendisinin, döviz kuru aktarım mekanizmasının etkisinin azalmasında etkili olduğunu vurgulamışlardır.

Büyükakın vd. (2009), 1990:01-2007:09 dönemi aylık verilerini ve VAR modelini kullanarak, döviz kuru kanalının etkinliğini test etmişler; döviz kurunda meydana gelen değişimlerin gelirler ve fiyat seviyesi üzerindeki etkisini ölçmeye çalışmışlardır. Analiz sonuçları, enflasyondaki değişimlerin açıklanmasında döviz kurlarının oldukça etkili olduğunu göstermiştir; başka bir deyişle, parasal aktarım mekanizmasında döviz kuru kanalının etkin bir şekilde çalıştığı sonucuna ulaşmışlardır.

Damar (2010), döviz kurlarından TÜFE ve çekirdek TÜFE'ye olan aktarım mekanizmasını, vektör hata giderme modeli çerçevesinde, dalgalı kur dönemi ve öncesi şeklinde iki dönem (1995-2000 ve 2002-2009) için incelemiş; enflasyon hedeflemesi rejiminin uygulandığ dönemde döviz kurunda meydana gelen değişikliklerin enflasyonu hangi büyüklük ve hızda etkilediğini bulmaya çalışmıştır. Analiz sonuçları, dalgalı kur rejiminin uygulanmasını izleyen dönemde, aktarım mekanizmasının üretim zinciri boyunca etkisinin azaldığına işaret etmektedir. Damar, bu durumu, enflasyon hedeflemesine geçiş ve ekonomideki yapısal dönüşüm sonucunda döviz kurunun, bekleyişleri şekillendiren referans değişken olmaktan çıkması ve endeksleme davranışının kırılması ile açıklarken, ekonomideki ithal girdi bağımlılığının yüksek düzeyde olmasının, döviz kurundan fiyatlara geçiş etkisini yapısal bir sorun olarak tutmaya devam ettirdiğini vurgulamıştır.

Yüncüler (2011), döviz kurları ve ABD Doları cinsinden ithal fiyatların tüketici fiyatları ve üretici fiyatlarına olan aktarım sürecini, enflasyon hedeflemesi rejimi öncesi ve sonrası dönem için analiz etmiştir. Analiz sonuçları, üretici fiyatlarına olan aktarım mekanizmasının tüketici fiyatlarına olan aktarım mekanizmasından daha etkin olduğuna işaret etmiştir. Bununla beraber, geçişkenliğin derecesi, enflasyon hedeflemesi döneminde, enflasyon hedeflemesi öncesi döneme göre önemli ölçüde daha düşük görünmektedir.

Cambazoğlu ve Karaalp (2012), 2003:01-2010:08 dönemi aylık verilerini kullanarak, döviz kuru kanalı aktarım mekanizmasının toplam üretim ve fiyat düzeyi üzerindeki etkinliğini VAR modelini kullanarak analiz etmişlerdir. Analizlerinde, reel efektif kur, kısa vadeli faiz oranı, net ihracat hacmi, tüketici fiyat endeksi ve sanayi üretim endeksi olmak üzere beş makroekonomik değişkeni kullanmışlar ve döviz kuru kanalının Türkiye'de etkin işlediği sonucuna ulaşmışlardır.

Güven ve Uysal (2013), 1983-2012 dönemi verilerini kullanarak, döviz kurlarındaki değişimlerin enflasyon üzerindeki etkisini araştırmışlar; reel efektif döviz kuru ve tüketici fiyat endeksi arasında çift yönlü bir nedensellik ilişkisi bulmuşlardır. Diğger yandan, değişkenler arasında bir eşbütünleşme ilişkisinin tespit edilmemiş olması, reel efektif kur ve enflasyon arasında uzun dönemde bir ilişkinin olmadığını göstermektedir.

Bozdağlıŏlu ve Yılmaz (2015), 1994-2014 dönemi verilerini ve VAR modelini kullanarak döviz kuru ile enflasyon arasındaki ilişkiyi analiz etmişler ve nominal döviz kurlarının enflasyon üzerinde etkili olduğunu bulmuşlardır. Enflasyonda meydana gelen şokların ise nominal kurlar üzerinde bir etkisi olmadığı sonucuna ulaştıkları çalışmalarında, Türkiye'de enflasyonun 
önlenmesinde, döviz arzını arttırıcı politikaların desteklenmesi gerektiğine işaret etmişlerdir.

Erarslan ve Katı (2015), 2003:Ç1-2012:Ç4 dönemi verilerini ve VAR modelini kullanarak, döviz kuru kanalının reel ekonomik değişkenler üzerindeki etkisini incelemişlerdir. Kısa vadeli faiz oranı, reel döviz kuru, net ihracat hacmi ve gayri safi yurt içi hasıla değişkenleri kullanılarak yapılan analizde, Cambazoğlu ve Karaalp (2012)'in aksine, döviz kuru kanalının Türkiye'de etkin bir biçimde işlemediği sonucuna ulaşılmıştır.

Duman (2016), 2003-2015 dönemi çeyreklik verilerini ve VAR modelini kullanarak, döviz kuru kanalının etkinliğini test etmiş; TÜFE'deki değişimlerin bir kısmının reel döviz kuru ve faiz oranı değişkenlerinin geçmiş değerleriyle açıklanmasının mümkün olduğunu, dolayısıyla döviz kuru kanalının Türkiye'de etkin çalıştığını belirtmiştir.

Özmen ve Topaloğlu (2017), döviz kuru ve ithal fiyatların parasal aktarım mekanizmasındaki etkilerini, 2005-2015 dönemi için analiz etmişlerdir. Tüketici fiyat endeksinin 152 alt bileşenini kullanarak yaptıkları çalışmada, TÜFE alt bileşenleri arasında aktarım katsayılarında önemli bir değişkenlik olduğunu bulmuşlardır. İthal fiyatların mal ve hizmetlerin yanı sıra, çekirdek mal ve enerji grubunda da etkili olduğu sonucuna ulaşmışlardır.

\section{Ekonometrik Uygulama}

\subsection{Veri ve Metodoloji}

Döviz kurundaki değişimler, direkt olarak ve hızlı bir şekilde, ülke içerisindeki malların fiyatlarına yansımaktadır. Aynı zamanda, döviz kurlarında ülke parası aleyhine yaşanan değişimler, ithal malların ülke parası cinsinden değerini arttırmakta ve bu yolla enflasyonunun yükselmesine yol açmaktadır. Türkiye'de 2017 ve 2018 yıllarında enflasyon tekrar çift haneli rakamları görmüş; döviz kurlarında Türk Lirası aleyhine yaşanan değerlenme, enflasyonda yaşanan belirgin yükselişteki majör faktör olmuştur. Bu çalışmada, 2003:01-2018:12 dönemi için, reel efektif kur ile tüketici fiyat endeksi arasındaki ilişki analiz edilmektedir. Aşağıda, RER ve TÜFE'nin 2003:01-2008:12 dönemindeki trendini içeren grafiklere yer verilmiştir.

Grafik 1: Reel Efektif Döviz Kuru, 2003:01-2018:12

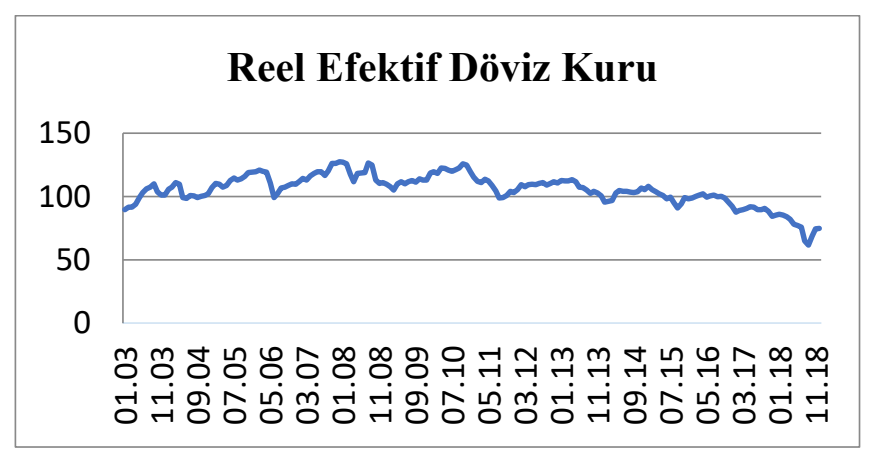

Kaynak: TCMB Elektronik Veri Dağıtım Sistemi

Grafik 2: Tüketici Fiyat Endeksi, 2003:01-2018:12

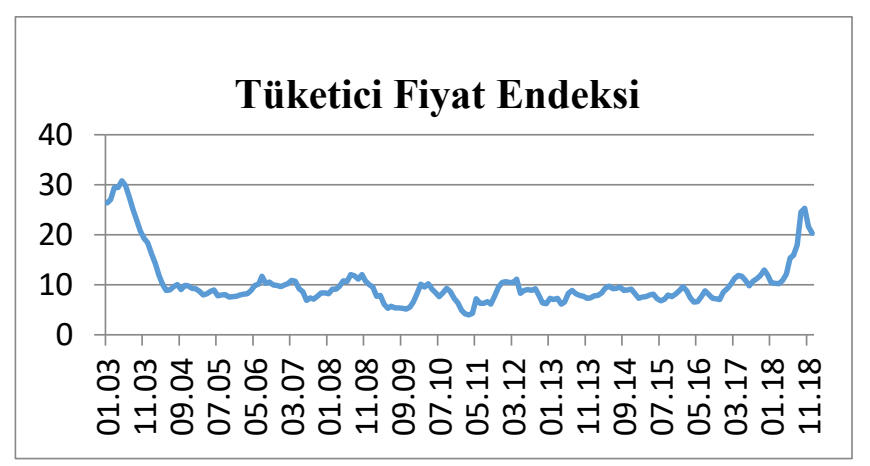

Kaynak: TÜİK İstatistik Veri Tabanı

Aşağıdaki tabloda, analizde kullanılan bağımlı-bağımsız değişkenlere ve söz konusu değişkenlerin kısaltmaları ile değişkenler arasında beklenen ilişkiye yer verilmiştir. $\mathrm{Bu}$ doğrultuda, bağımlı değişken olarak TÜFE ve bağımsız değişken olarak RER arasındaki ilişki analiz edilmeye çalışılmıştır. Çalışmada kullanılan reel efektif döviz kuru verileri TCMB Elektronik Veri Dağıtım Sistemi'nden, tüketici fiyat endeksi verileri ise TÜİK İstatistik Veri Tabanı'ndan elde edilmiştir.

Tablo 1: Uygulamada Kullanılan Bağımlı ve Bağımsız Değişkenler

\begin{tabular}{llll}
\hline & Değişkenler & Kısaltma & Beklenen Etki \\
\hline Bağımlı Değişken & Tüketici Fiyat Endeksi & TÜFE & $(+)$ \\
Bağımsız Değişken & Reel Efektif Kur(TÜFE Bazlı) & RER & \\
\hline
\end{tabular}

Bu çalışmada, RER ile TÜFE arasındaki kısa ve uzun dönemli ilişki, Fourier SHIN eşbütünleşme testi ve Fourier Granger nedensellik testi yardımiyla incelenmektedir. Öncelikle, serilerdeki entegrasyonun düzeyini belirlemek amacıyla birim kök testi yapılmaktadır. Ekonomik zaman serilerinin durağanlığının test edilmesi büyük öneme sahiptir. Bu nedenle, öncelikle, ADF ve Fourier ADF birim kök testleri yardımıyla serilerin durağanlığı test edilmektedir. Çalışmada Fourier ADF birim kök testi kullanılmasının amacı, bu yöntemin birden fazla yapısal değişimin düşük frekanslı Fourier fonksiyonlarıyla tahmin edilmesine olanak sağlamasıdır. Diğer birçok yöntemin aksine, yapısal değişimin sayı ve konumunu bilmek zorunluluğu ortadan kalkmaktadır. İzleyen aşamada ise, değişkenler arasındaki uzun dönemli ilişkinin varlığını test etmek amaciyla Fourier SHIN koentegrasyon testi kullanılmaktadır. Bu test, literatürdeki birçok eşbütünleşme testinin aksine temel hipotez altında eşbütünleşmenin yokluğunun aksine, söz konusu ilişkinin varlığını test etmektedir. FKPSS durağanlık testinin eşbütünleşme için 
genişletilmiş hali niteliğinde olan Fourier eşbütünleşme testi, yapısal değişimlerin formuna ve sayısına karşın güçlü sonuçlar türetmektedir. Son olarak, üçüncü aşamada değişkenler arasındaki nedensellik ilişkisinin araştırılması amaciyla Fourier Granger nedensellik testine başvurulmaktadır. Değişkenler arasındaki bağlantılar, yapısal kırılmalara maruz kaldığı ve aynı zamanda doğrusal spesifikasyonlar bu ilişkileri yakalamakta çoğu zaman yetersiz kaldığ geldiği görülmektedir. Bu doğrultuda, Fourier Granger nedensellik testinde, esnek Fourier formu kullanılarak, VAR sistemi içerisinde var olan yumuşak kırılmalar yakalanmaya çalışılmaktadır.

\subsection{Analiz ve Sonuçlar}

Enders ve Lee (2012), çalışmalarında, bir veya daha fazla yapısal değişimin düşük frekanslı Fourier fonksiyonlarıyla tahmin edilebileceğini belirtmektedir. Fourier ADF birim kök testinin uygulanması sırasında, yapısal değişimin konum ve sayısından ziyade, Fourier fonksiyonunun uygun frekans sayısının bilinmesi önem taşımaktadır.
Testin ilk aşamasında aşağıdaki model tahmin edilmektedir: $\Delta \mathrm{y}_{\mathrm{t}}=\rho \mathrm{y}_{\mathrm{t}-1}+\beta_{1}+\beta_{2}$ trend $+\beta_{3} \sin (2 \pi k t / T)+\beta_{4} \cos (2 \pi k t / T)$ $+u_{t}$

Burada t trendi, T örneklem sayısını ve $\pi=3.1416$ 'yı ifade etmekte olup; k'nın optimal değerini bulabilmek için, k yerine 1-5 aralığındaki değerler kullanılıp model tahmin edilmekte ve en küçük KKT'yi veren k’ya ulaşılmaya çalışılmaktadır. Uygun olduğu tespit edilen k'nın olduğu modelde, otokorelasyon sorunu olması halinde, bağıml değişkenin gecikmeli değerleri modele dahil edilmektedir. Serinin durağan çıkması halinde ise, trigonometrik terimlerin anlamlılı̆̆ını sınamak için F testi kullanılmaktadır.

$\beta_{3}=\beta_{4}=0$

Uygun kritik değerler, Enders ve Lee (2012) makalesinde yer almaktadir.

\section{Tablo 2: ADF ve Fourier ADF Birim Kök Test Sonuçları(T=192)}

\begin{tabular}{lccccc} 
Seriler & Frekans & MinKKT & $\begin{array}{l}\text { Fourier ADF } \\
\text { t- istatistiği }\end{array}$ & ADF t-istatistiği & $\begin{array}{l}\text { Fourier ADF } \\
\text { F-istatistiği }\end{array}$ \\
\hline TÜFE & 3 & 227.6506 & $-2,624050$ & - & - \\
Fark TÜFE & 3 & 209.9870 & $-9,653911 * * *$ & $-9,451102 * * *$ & - \\
RER & 5 & 1861.109 & $-1,233410$ & - & 0,408383 \\
Fark RER & 5 & 1751.933 & $-10,53631 * * *$ & $-10,80571 * * *$ & - \\
\hline
\end{tabular}

Not: Tabloda, k, MinKKT değerini veren optimal frekans değerini göstermektedir. Fourier ADF t-istatistiği için kritik değerler; k=3 ve T=192 için, $\% 1, \% 5$ ve $\% 10$ için sırasıyla, $-3,74,-3,06,-2,72$ ve $\mathrm{k}=5$ ve $\mathrm{T}=192$ için, $\% 1, \% 5$ ve $\% 10$ için sırasıyla, $-3,55,-2,94$ ve $-2,62$ 'dir. Fourier ADF F-istatistiği için kritik değerler, T=192 için, \%1, \%5 ve \%10 için sırasıyla, 10,02, 7,41 ve 6,25'tir. Çalışmada, trend içermeyen model kullanıldığı için, Enders ve Lee (2012)'nin çalışmasında yer alan Tablo 1(b)'deki değerleri dikkate alınmaktadır. ADF t-istatistiği için kritik değerler ise, $\% 1, \% 5$ ve $\% 10$ için sırasıyla, $-3,46,-2,87$ ve $-2,57$ 'dir. ***, ** ve *, sırasıyla $\% 1, \% 5$ ve $\% 10$ istatistiki anlamlılık düzeyini göstermektedir.

Test sonuçlarına göre, serilerin birim köklü olduğu anlaşılmış olup; seriler farkları alındıktan sonra durağan hale gelmektedir. Farkları alındığında durağan hale gelen seriler için F-istatistikleri aynı makalede geçen Fistatistikleri ile karşılaştırılarak trigonometrik değerlerin anlamlılığı sınanmış; trigonometrik değerlerin anlamlı olmadığı anlaşılmıştır. Sonrasında, ADF testi uygulanmış ve tüm değişkenlerin I(1) seviyesinde durağan olduğu görülmüştür.

İkinci aşamada, Fourier SHIN eşbütünleşme testi uygulanacaktır. Tsong vd. (2016) tarafindan Fourier fonksiyonlarının kullanılmasıyla elde edilen eşbütünleşme testi, temel hipotez altında eşbütünleşmenin yokluğunu değil varlığını sınamaktadır. FKPSS durağanlık testinin eşbütünleşme için genişletilmiş hali niteliğinde olan Fourier eşbütünleşme testi, yapısal değişimlerin formuna ve sayısına karşın güçlü sonuçlar türetmektedir (Yılanc1, 2017: 58).
Tsong vd. (2016) tarafından geliştirilen eşbütünleşme regresyonu aşağıda yer almaktadır:

$y_{t}=d_{t}+\dot{x}_{t} \beta+\eta_{t}, \mathrm{t}=1,2, \ldots ., \mathrm{T}$,

Burada, $\eta_{t}=\gamma_{t}+v_{1 t}, \gamma_{t}=\gamma_{t-1}+u_{t}, \gamma_{0}=0$ ve $x_{t}=$ $x_{t-1}+v_{2 t}$. olup; $u_{t}$, sifir ortalama $\sigma_{u}{ }^{2}$ varyansla ve $\gamma_{t}$, sifir ortalama ile rassal bir yürüyüş sürecini göstermektedir. (3) numaralı denklemde yer alan deterministik unsur olan $d_{t}$ aşağıdaki şekilde tahmin edilmektedir:

$d_{t}=\sum_{i=0}^{m} \delta_{i} t^{i}+f_{1}$

$\mathrm{m}=0$ veya $\mathrm{m}=1$ olması durumunda,

$f_{t}=\alpha_{k} \sin \left(\frac{2 k \pi t}{T}\right)+\beta_{k} \cos \left(\frac{2 k \pi t}{T}\right)$

Burada, k Fourier frekans değerini, t trendi ve $\mathrm{T}$ ise gözlem sayısını göstermektedir. Eşbütünleşme olmadığını gösteren alternatif hipoteze karşın sıfır hipotez, aşağıdaki şekilde belirtilmektedir:

$H_{0}: \sigma_{u}^{2}=0$ karş1 $H_{1}: \sigma_{u}^{2}>0$ 
(6) numaralı denklemde yer alan sıfır hipotezi altında, (3) ve (5) numaralı denklemler, aşağıdaki şekilde tekrar oluşturulabilmektedir:

$$
\begin{aligned}
& y_{t}=\sum_{i=0}^{m} \delta_{i} t^{i}+\alpha_{k} \sin \left(\frac{2 k \pi t}{T}\right)+\beta_{k} \cos \left(\frac{2 k \pi t}{T}\right)+\dot{x}_{t} \beta+ \\
& v_{1 t}
\end{aligned}
$$

$\mathrm{CI}_{\mathrm{f}}^{\mathrm{m}}$ ile sembolize edilen FSHIN eşbütünleşme test istatistiği aşağıdaki şekilde belirtilmektedir:

$C I^{m}=T^{-2} \widehat{\omega}^{-2}{ }_{1} \sum_{t=1}^{T} S_{t}^{2}$

Burada, $S_{t}=\sum_{t=1}^{T} \hat{v}_{1 t}(8)$ numaralı denklemden elde edilen EKKY kalıntılarının kısmi toplamını ve $\widehat{w}_{1}^{2}, v_{1 t}$ 'nin uzun dönem varyansının tutarlı tahmincisini göstermektedir.

Tablo 3: Fourier SHIN Eşbütünleșme Test Sonuçları

\begin{tabular}{llllc}
\hline Frekans(k) & Min EKKY & $\begin{array}{l}\text { Fourier Eşbütünleşme } \\
\text { Test İstatistiği }\end{array}$ & $\begin{array}{l}\text { Shin Eşbütünleşme } \\
\text { Test İstatistiği }\end{array}$ & F-istatistiği \\
\hline 3 & 205.8468 & $0,247007^{* *}$ & $0,327926^{* * *}$ & 1,114307 \\
\hline
\end{tabular}

Not: Tabloda, $m=0, k=3$ ve $p=1$ için, Fourier eşbütünleşme test istatistiği kritik değerleri; $\% 1, \% 5$ ve $\% 10$ için sırasıyla, $0,507,0,304$ ve 0,225 iken; F istatistiği kritik değerleri; \%1, \%5 ve \%10 için sırasıly, 5,774, 4,066 ve 3,352'dir. SHIN test istatistiği için kritik değerleri ise; \%1, $\% 5$ ve $\% 10$ için sırasıyla, $0,553,0,314$ ve 0,231 'dir. ***, ** ve *, sırasıyla $\% 1, \% 5$ ve $\% 10$ istatistiki anlamlılık düzeyini göstermektedir.

Tablo 3, Fourier eşbütünleşme ve SHIN eşbütünleşme test sonuçlarını göstermektedir. Fourier eşbütünleşme testi sonuçlarına göre, test istatistiği anlamlıdır ve reel efektif kur ile tüketici fiyat indeksi arasında uzun dönemli bir ilişki olduğu görülmektedir. Bununla beraber, trigonometrik terimlerin anlamlılı̆̆ının sınanması amacıyla, analiz sonucunda elde edilen F-istatistiği değerleri, çalışmada yer alan F-istatistiği kritik değerleriyle karşılaştırılmış ve trigonometrik değerlerin anlamlı olmadığı görülmüştür. $\mathrm{Bu}$ nedenle, SHIN eşbütünleşme testi uygulanmış ve test sonuçlarının RER ve TÜFE arasında uzun dönemli bir ilişkinin varlığını desteklediği anlaşılmıştır. Buna göre, RER'deki değişimler, TÜFE üzerinde uzun dönemli etkiye sahiptir.

İzleyen aşamada, Enders ve Jones (2016) tarafindan geliştirilen Fourier Granger nedensellik testi yapılarak, değişkenler arasında bir nedensellik ilişkisinin olup olmadığı araştırılmaktadır. Değişkenler arasındaki bağlantılar, yapısal kırılmalara maruz kaldığ 1 ve aynı zamanda lineer spesifikasyonlar bu ilişkileri yakalamakta çoğu zaman yetersiz kaldığı için, ekonometrik analizlerin karmaşık hale geldiği görülmektedir. Enders ve Jones (2016), esnek Fourier formu kullanarak, VAR sistemi içerisinde varolan yumuşak kırılmaları yakalamaya çalışmışlar ve Granger nedensellik testlerini kullanarak kısa dönemli dinamikler üzerine yoğunlaşmışlardır.

Kırılmaların sayısını, oluşumunu ve büyüklüğünü tahmin etmek yerine, Enders ve Jones (2016) VAR sisteminde varolan kırılmaları kontrol etmek için esnek Fourier formu denemişler ve değişkenlerin durağanlığını test ettikten sonra, doğrusal VAR denklemini aşağıdaki şekilde tanımlamışlardır:

$z_{t}=\delta+\sum_{i=1}^{11} A_{i} z_{t-i}+e_{t}$

Burada, $\delta$, sabit terimlerin $(4 \times 1)$ bir vektörü olup; $A_{i},(4 \times 4)$ vektör katsayısı ve $e_{t}$ ise değişikliklerin bir vektörüdür. Bununla beraber, iki nedenle problemli sonuçlar ortaya çıkabilmektedir. Farkedilmeyen yapısal değişimler nedeniyle, (9) numaralı denklem yanlış tanımlanmış olabilmekte ve aynı zamanda, denklemdeki güven aralıkları gereksiz şekilde geniş tanımlanabilmektedir. Dolayısıyla, Enders ve Jones (2016), (9) numaralı VAR denkleminin yerine, deterministik regresörleri aşağıdaki şekilde belirlemişlerdir:

$z_{t}=\delta(t)+\sum_{i=1}^{11} A_{i} z_{t-i}+e_{t}$
$\delta(t)=\left[\delta_{1}(t), \delta_{2}(t), \delta_{3}(t), \delta_{4}(t)\right]^{\prime}$

ve her sabit $\delta_{i}$ aşağıdaki şekilde n tane Fourier frekansına bağlı olmaktadır:

$$
\begin{aligned}
& \delta_{i}(t)=a_{i}+b_{i} t+\sum_{k=1}^{n} a_{i k} \sin \left(\frac{2 \pi k t}{T}\right)+ \\
& b_{i k} \cos \left(\frac{2 \pi k t}{T}\right)
\end{aligned}
$$

Kırılmaların kontrol edilmesinde Fourier terimleri kullanıldığı zaman, Granger nedensellik testleri, daha önce elde edilen sonuçlardan önemli ölçüde farklılaşmaktadır. Enders ve Jones (2016) modele trigonometrik fonksiyonları ekleyerek, değişkenler arasında çok daha güçlü ilişkiler tespit etmişlerdir. 
Tablo 4: Fourier Granger Nedensellik Testi Sonuçları

\begin{tabular}{ccllc}
\hline Optimal Frekans & Wald-stat & Asymptotik p-değeri & Bootstrap p-değeri & Optimal Gecikme \\
\hline 1 & 27.577 & $0,006^{* * *}$ & 0,009 & 12 \\
3 & 24.891 & $0,015^{* *}$ & 0,034 & 12 \\
3 & 12.232 & 0,427 & 0,455 & 12 \\
1 & 13.547 & 0,331 & 0,336 & 12 \\
\hline RER $\rightarrow$ TÜFE (Single frequency) & & & \\
RER $\rightarrow$ TÜFE (Cumulative frequency) & &
\end{tabular}

Not: $\rightarrow$ nedenselliğe işaret etmektedir. Optimal k (frekans) ve p (gecikme) değerleri Akaike Bilgi Kriteri’ne göre belirlenmiştir. ***, ** ve *, sırasıyla \%1, \%5 ve \%10 istatistiki anlamlılık düzeyini göstermektedir. Bu çalışmada T (örneklem sayıs1) $>50$ olduğu için, analizde asimptotik p-değeri kullanılmaktadır.

Tablo 4'de Fourier Granger nedensellik testi sonuçları yer almaktadır. Analiz sonuçlarına göre, Granger Single Frequency ve Granger Cumulative Frequency için sırasıyla, asimptotik p-değeri 0,05'ten küçük bir değer aldığı için, reel efektif döviz kurundan tüketici fiyat endeksine doğru bir nedensellik ilişkisi bulunmaktadır. Buna göre, RER'deki değişimler, TÜFE üzerinde kısa dönemde bir etkiye sahiptir. Diğer yandan, tablodan görüleceği üzere, TÜFE'den RER'e herhangi nedensellik tespit edilmemiştir.

\section{Sonuç}

Küresel krizle birlikte dünyada birçok ülkede, enflasyon oranlarında belirgin düşüşler yaşanmıştır. Bununla beraber, Türkiye'de, 2001 Krizi sonrasında uygulanan mali disiplin ve yapisal reformlar neticesinde enflasyonda tek haneler görülmesine rağmen, global faktörler ve jeopolitik riskteki artış nedeniyle yaşanan döviz kurunda yaşanan değerlenme, enerji ve gıda fiyatlarındaki artışlar, 2017 yılı ve 2018 yılında, tekrar çift haneli enflasyon oranlarının görülmesine yol açmıştır. Özellikle, 2018 yılında yıllık enflasyonda yaşanan artışta, döviz kurlarındaki şiddetli dalgalanma, enerji fiyatlarındaki artış ve gıda fiyatlarındaki yükselişler, majör faktörler olmuştur. Türk Lirası'nda, ülke içinde politik riskteki artışın yanı sıra, küresel piyasalarda yaşanan belirsizlikler nedeniyle, özellikle 2018 yılının 2. yarısında belirgin bir değer kaybı yaşanmıştır. Gıda fiyatlarındaki yukarı yönlü trend, hem mal hem hizmet enflasyonunu olumsuz yönde etkilemiş ve 2018 yılında yıllık tüketici enflasyonu, belirsizlik aralığının üzerinde seyretmiştir.

2018 yılı ikinci yarısında yaşanan küresel ve jeopolitik şokların yanı sıra, yurt içinde artan politik riskin sonucunda döviz kurlarında yaşanan şiddetli dalgalanmaya cevaben, Merkez Bankası, parasal sıkılaştırma yapmış; para politikası faiz oranlarında belirgin bir faiz artırımına gitmiştir. Aynı zamanda, 2018 yılında, TCMB tarafından, Rezerv Opsiyon Mekanizması (ROM) kapsamında dövize ilişkin üst sınırın indirilmesi, yabancı para zorunluk karşılık oranlarının arttırılması, kısa vadeli reeskont kredilerinin geri ödemesinin TL cinsinden yapilabilmesine imkan tanınması gibi adımlar atılarak, kurdaki yukarı hareketler sınırlandırılmaya çalışılmıştır. Enflasyonun 2002 sonrasında tek hanelere düşürülmesinde uygulanan mali disiplinin ve TCMB'nin uyguladığı politikaların katkısı büyüktür. Ancak, özellikle döviz kurunda yaşanan aşırı değerlenme ve gıda fiyatlarındaki artış nedeniyle, son dönemde belirlenen hedeften uzaklaşıldığı görülmektedir.

TCMB tarafindan yayımlanan Enflasyon IV. Çeyrek Raporu (2018)'na göre, 2018 yılı enflasyon oranının yüksek çıkması ve enflasyon beklentilerinin fiyatlama davranışı üzerinde risk oluşturmaya devam etmesi, enflasyonda önümüzdeki dönemde yukarı trendi destekler görünmektedir. Döviz kurlarındaki hareketlerin ve faiz artırımlarına paralel firma finansman giderlerindeki artışların maliyet unsurları üzerinde yarattığı baskıların, enflasyon üzerinde kısa ve orta dönemde belirleyici unsurlar olmaya devam edeceği tahmin edilmektedir. Diğer yandan, ekonomik yavaşlamaya paralel olarak, talepte görülen kısmi daralmanın, enflasyona olumlu yansıması beklenmektedir. Bu çalışmada, reel efektif kur ile tüketici fiyat endeksi arasındaki eşbütünleşme ve nedensellik ilişkisi, Fourier SHIN kointegrasyon ve Fourier Granger nedensellik testleri ile analiz edilmiş; RER ve TÜFE arasında kısa ve uzun dönemli ilişkiler olduğu tespit edilmiştir. Çalışma sonuçlarının, Gül ve Ekinci (2006), Büyükakın vd. (2009), Cambazoğlu ve Karaalp (2012), Bozdağlıoğlu ve Yılmaz (2015), Duman (2016), Özmen ve Topaloğlu (2017) tarafindan yapılan çalışmalara ait sonuçlarla tutarlı olduğu görülmektedir. Reel efektif kur ve tüketici fiyat enflasyonu arasında ortaya çıkan kısa ve uzun dönemli ilişki, döviz kurunda Türk Lirası aleyhine yaşanacak değerlenmenin, gelecek dönemde enflasyonu olumsuz yönde etkilemeye devam edeceğine işaret etmektedir. Dolayısıyla, önümüzdeki dönemde, TCMB tarafından uygulanan para politikasının etkinliği, hem döviz kuru-enflasyon sarmalının kırılabilmesi, hem de enflasyonist beklentiler üzerindeki etkisi açısından önem arz etmektedir.

\section{Kaynakça}

Andıç, S., Küçük, H. \& Öğünç, F., 2015. Inflation dynamics in Turkey: in pursuit of a domestic cost measure. Emerging Markets Finance and Trade, 51(2), pp.418431. 
Aron, J., Macdonald, R. \& Muellbauer, J. (2014). Exchange rate pass-through in developing and emerging markets: a survey of conceptual, methodological and policy issues and selected empirical findings, Journal of Development Studies, 50(1), 101-143.

Bozdağlıŏlu, Y. \& Yılmaz, M. (2015). Türkiye'de enflasyon ve döviz kuru ilişkisi: 1994-2014 yılları arası bir inceleme, BEU Akademik İz düşüm, 2(3), 1-20.

Büyükakın, F., Cengiz, V. \& Türk, A. (2009). Parasal aktarım mekanizması: Türkiye'de döviz kuru kanalının VAR analizi”, Dokuz Eylül Üniversitesi İktisadi ve İdari Bilimler Fakültesi Dergisi, 24(1), 171-198.

Cambazoğlu, B. \& Karaalp, H. S. (2012). Parasal aktarım mekanizması döviz kuru kanalı: Türkiye örneği”, Yönetim ve Ekonomi Dergisi, 19(2), 53-66.

Damar, A.O. (2010). Türkiye'de döviz kurundan fiyatlara geçis etkisinin incelenmesi, TCMB Uzmanlık Yeterlilik Tezi, $\quad$ 1-67. 08.12.2018 tarihinde http://www3.tcmb.gov.tr/kutuphane/TURKCE/tezler/ar maganonurdamar.pdf adresinden ulaşılmıştır.

Duman, Y.K. (2016). Parasal aktarım mekanizması döviz kuru kanalı: Türkiye, Uluslararası Hakemli Ekonomi Yönetimi Araştırmaları Dergisi, 09, 1-24.

Dünya Bankası (2018). Global economic prospects: broadbased upturn, but for how long?, January 2018. 08.03.2018 tarihinde http://documents.worldbank.org/curated/en/965861515 772893243/Global-economic-prospects-broad-basedupturn-but-for-how-long adresinden ulaşılmıştır.

Enders, W. \& Lee, J. (2012). The flexible Fourier form and the Dickey-Fuller type unit root tests, Economics Letters, 117, 196-199.

Enders, W. \& Jones, P. (2016). Grain prices, oil prices and multiple smooth breaks in a VAR, Studies in Nonlinear Dynamics \& Econometrics, 20(4), 399-419.

Erarslan, C., \& Katı, E. (2015) Parasal aktarım mekanizması ve döviz kuru kanalı: Türkiye örneği, Dumlupınar Üniversitesi Sosyal Bilimler Dergisi, 44, 79-91.

Gül, E. \& Ekinci, A. (2006). Türkiye'de enflasyon ve döviz kuru arasındaki nedensellik ilişkisi: 1984-2003, Anadolu Üniversitesi Sosyal Bilimler Dergisi, 6(1), 91106.

Güven, E.T.A \& Uysal, D. (2013). Türkiye'de döviz kurlarındaki değişme ile enflasyon arasındaki ilişki (1983-2012). Akademik Araştırmalar ve Çalışmalar Dergisi, 5(9), 141-156.

IMF (2018). Economic outlook report, 05.12.2018 tarihinde https://www.imf.org/en/Publications/WEO/Issues/2018 /09/24/world-economic-outlook-october-2018 adresinden ulaşılmıştır.
Kara, H., Küçük-Tuğer, H., Özlale, Ü., Tuğer, B. \& Yücel, M. E. (2007). Exchange rate regimes and pass-through: evidence from the Turkish economy. Contemporary Economic Policy, 25(2), 206-225.

Kara, H. \& Öğünç, F. (2008). Inflation targeting and exchange rate pass-through: the Turkish experience, Emerging Markets Finance and Trade, 44:6, 52-66.

Kara, H., Öğünç, F., Özmen, M. U. \& Sarıkaya, Ç. (2017). Exchange rate pass-through: is there a magical coefficient?", CBRT Blog, January 2017.

Özmen, M. U. \& Sarıkaya, Ç. (2014). Enflasyonun çıktı açığı ve kredilere duyarlılığı, TCMB Ekonomi Notları, 2014/17. 14.12.2018 tarihinde http://www.tcmb.gov.tr/wps/wcm/connect/a1d2cbf64183-412c-a5fd-

57c0104a2f51/EN1417.pdf?MOD=AJPERES\&CACH EID=ROOTWORKSPACE-a1d2cbf6-4183-412c-a5fd57c0104a2f51-m3fB86X adresinden ulaşılmıştır.

Özmen, M. U. \& Topaloğlu, M. (2017). Disaggregated evidence for exchange rate and import price passthrough in the light of identification issues, aggregation bias and heterogeneity, CBRT Working Paper, 17(08). 14.12.2008 tarihinde www.tcmb.gov.tr/wps/wcm/connect/3ac28a29-8e8a$\underline{4 \mathrm{dfe}-84 \mathrm{ad}-}$ 87c04b5c47ca/wp1708.pdf?MOD=AJPERES\&CACH EID=ROOTWORKSPACE-3ac28a29-8e8a-4dfe-84ad87c04b5c47ca-m3fB9wj

TCMB (2018). Enflasyon IV. çeyrek raporu 2018. 12.12.2018 tarihinde https://www.tcmb.gov.tr/wps/wcm/connect/79b2b4471137-4eb6-b5af-319e85798d14/ki184.pdf?MOD=AJPERES\&CACHEID=ROOTWORKSP ACE-79b2b447-1137-4eb6-b5af-319e85798d14mr9b58G adresinden ulaşılmıştır.

TCMB (2018). Elektronik veri dağıtım sistemi. 21.12.2018 tarihinde

https://evds2.tcmb.gov.tr/index.php?/evds/serieMarket adresinden ulaşılmıştır.

Tsong, C. C., Lee, C. F., Tsai, L. J. \& Hu, T. C. (2016). The Fourier approximation and testing for the null of cointegration, Empirical Economics, 51(3), 1085-1113.

TÜİK (2019). Resmi istatistik veri tabanı. 05.01.2019 tarihinde

http://www.tuik.gov.tr/UstMenu.do?metod=temelist adresinden ulaşılmıştır.

Yilanc1, V. (2017). Analyzing the relationship between oil prices and economic growth: a Fourier approach, Econometrics and Statistics, 27(2), 51-67.

Yüncüler, Ç. (2011). Pass-through of external factors into price indicators in Turkey. Central Bank Review, 11(2), 71-84. 